\title{
EVALUASI PENGUNGKAPAN LAPORAN KEUANGAN DAERAH DI SITUS INTERNET: STUDI PADA PEMERINTAH DAERAH INDONESIA
}

\author{
Gatot Soepriyanto $^{1}$; Restya Aristiani ${ }^{2}$ \\ ${ }^{1,2}$ Jurusan Akuntansi, Fakultas Ekonomi dan Bisnis, Bina Nusantara University \\ Jln. K.H. Syahdan No. 9, Kemanggisan, Palmerah, Jakarta Barat 11480 \\ gsoepriyanto@binus.edu
}

\begin{abstract}
The purpose of this study was to determine the extent of financial statement disclosure displayed on the website of local government in the years 2009-2010. The research method used is bibliography study and field study through the Internet. We found 2 types of financial information presented in the website, namely the information of financial statements and other financial information. There are 57 local governments that provide financial information from 392 local governments' website. The 57 local government web sites, only nine local governments that provide information on its financial statements in accordance to SAP (Government Accounting Standards), while 40 local governments provide information on local government budgets (APBD) and 8 present the financial information other than financial statements according to SAP and budget information (APBD). These findings suggest that transparency and accountability of local governments related to the financial statements and other financial information on the website is still lacking.
\end{abstract}

Keywords: transparency, disclosure, local government financial statements, internet web site

\begin{abstract}
ABSTRAK
Tujuan penelitian ini adalah untuk menentukan seberapa banyak pengungkapan laporan keuangan daerah yang ditampilkan pada situs web pemerintah daerah pada tahun 2009-2010. Metode penelitian yang digunakan adalah studi kepustakaan dan studi lapangan melalui internet. Dari hasil pengamatan terhadap situs web pemerintah daerah, maka ditemukan 2 jenis informasi keuangan yang disajikan, yaitu informasi laporan keuangan dan informasi keuangan lainnya. Terdapat 57 pemerintah daerah yang menyajikan informasi keuangan di situs webnya dari 392 pemerintah daerah yang memiliki situs web. Dari ke 57 situs web pemerintah daerah tersebut, hanya 9 pemerintah daerah yang menyajikan informasi laporan keuangannya sesuai SAP (Standar Akuntansi Pemerintah), 40 pemerintah daerah menyajikan informasi APBD dan 8 pemerintah daerah menyajikan informasi keuangan selain laporan keuangan menurut SAP dan informasi APBD. Temuan ini menunjukkan bahwa transparansi dan pertanggungjawaban pemerintah daerah terkait laporan keuangan dan informasi keuangan lainnya di situs web masih sangat kurang.
\end{abstract}

Kata kunci: transparansi, pengungkapan, laporan keuangan daerah, situs web internet 


\section{PENDAHULUAN}

Perhatian terhadap masalah transparansi dan akuntabilitas keuangan sektor publik di Indonesia semakin meningkat. Hal ini disebabkan oleh krisis ekonomi dan masalah kepercayaan publik kepada pemerintah dalam pengelolaan keuangan negara. Salah satu konsekuensinya, pemerintah harus mampu meningkatkan transparansi dan akuntabilitas pengelolaan keuangan negara (pusat dan daerah). Hal ini tertuang dalam Peraturan Menteri Dalam Negeri (Permendagri) Nomor 13 Tahun 2006 Tentang Pedoman Pengelolaan Keuangan Daerah. Salah satu upaya untuk mewujudkan transparansi dan akuntabilitas adalah penyampaian informasi laporan keuangan daerah. Pemerintah harus mampu menyediakan semua informasi keuangan daerah secara relevan, jujur dan terbuka kepada publik. Dimana, rakyat sebagai pemberi amanah (principal) memiliki hak untuk mengetahui kemana saja aliran dana digunakan. Disisi lain, Pemerintah sebagai pemegang amanah (agent) mempunyai tangung jawab untuk mengelola, menyajikan dan mempublikasikan informasi laporan keuangan kepada publik. Dalam kaitannya untuk menyajikan laporan keuangan daerah, telah diterbitkan Peraturan Pemerintah (PP) No. 24 Tahun 2005 tentang Standar Akuntansi Pemerintah. Peraturan tersebut menuntut kepada pemerintah daerah untuk menyiapkan laporan keuangan daerah terdiri: Laporan Realisasi Anggaran, Neraca, Laporan Arus Kas dan Catatan atas Laporan Keuangan.

Dalam proses publikasi informasi keuangan daerah, internet dapat menjadi salah satu media informasi. Internet mendukung kemajuan dan penyampaian informasi kepada masyarakat luas. Searah dengan kondisi tersebut, pemerintah juga menggalakkan untuk memanfaatkan media internet sebagai penyampaian informasi. Salah satu langkah yang dilakukan adalah membangun situs web (website) resmi pemerintah pusat dan daerah. Penggunaan internet sebagai media penyampaian informasi keuangan daerah, telah dilakukan di New Zealand. Berdasarkan penelitian yang dilakukan oleh Laswad, Fisher \& Oyelere (2005), beberapa pemerintahan lokal di New Zealand memilih untuk menyediakan pengungkapan pelaporan keuangan di internet. Hasil penelitian atas pengungkapan dengan internet memberikan pengembangan akan kegiatan transparansi dan akuntabilitas terhadap pelaporan keuangan di New Zealand.

Hal inilah yang menjadi salah satu faktor pendorong bagi peneliti, untuk melakukan penelitian atas kegiatan transparansi dan akuntabilitas pengungkapan laporan keuangan daerah di Indonesia. Akan tetapi dalam penelitian ini fokus utamanya adalah untuk mengetahui (1) apakah transparansi pelaporan keuangan daerah dipublikasi di situs web pemerintah daerah, (2) untuk menilai kelengkapan pengungkapan informasi keuangan pada situs web pemerintah daerah yang disesuaikan dengan kriteria pengukuran penelitian ini serta (3) untuk mengevaluasi kualitas pengungkapan laporan keuangan yang telah disajikan dalam situs web pemerintah daerah dan kesesuainya dengan Estándar Akuntansi Pemerintah (SAP).

\section{Tinjauan Literatur}

\section{Reformasi Akuntansi Sektor Publik}

Menurut Halim (2007) bahwa perkembangan akuntansi sektor publik di Indonesia khususnya akuntansi keuangan daerah di mulai pada tahun 1999. Hal ini ditandai dengan pelaksanaan otonomi daerah. Pelaksanaan otonomi daerah menjadi dasar utama dalam perubahan pengelolaan keuangan daerah yang menuntut untuk lebih transparansi dan akuntabilitas. Selain itu, di dalam proses sistem akuntansi telah mengalami perubahan yaitu dengan menggunakan sistem pencatatan ganda (double entry system) dan basis pencatatan atas dasar kas modifikasian (modified cash basis) yang mengarah pada basis akrual (accrual basis) (Bastian \& Soepriyanto, 2002).Serta pemerintah juga harus menerapkan konsep $3 \mathrm{E}$ (value for money) yaitu efektif, efisien dan ekonomis dalam pengelolaan anggaran. Dengan demikian pemerintah daerah saat ini dituntut untuk mampu membuat laporan 
keuangan daerah yang sesuai dengan standar akuntansi pemerintah yaitu sesuai dengan PP nomor 24 tahun 2005. Hal ini merupakan upaya konkret untuk meningkatkan terwujudnya transparansi dan akuntablitas laporan keuangan daerah.

\section{Laporan Keuangan Pemerintah Daerah}

Menurut Mardiasmo (2002) bahwa laporan keuangan organisasi sektor publik merupakan komponen penting untuk menciptakan akuntabilitas sektor publik. Adanya tuntunan yang semakin besar terhadap pelaksanaan akuntabilitas publik menimbulkan implikasi bagi manajemen sektor publik untuk memberikan informasi kepada publik, salah satunya adalah informasi akuntansi yang berupa laporan keuangan. Komite Standar Akuntansi Pemerintah (2005) dalam paragraf 9 menyatakan bahwa: Laporan keuangan merupakan laporan yang terstruktur mengenai posisi keuangan dan transaksitransaksi yang dilakukan oleh suatu entitas pelaporan. Tujuan umum laporan keuangan adalah menyajikan informasi mengenai posisi keuangan, realisasi anggaran, arus kas, dan kinerja keuangan suatu entitas pelaporan yang bermanfaat bagi para pengguna dalam membuat dan mengevaluasi keputusan mengenai alokasi sumber daya. Secara spesifik, tujuan pelaporan keuangan pemerintah adalah untuk menyajikan informasi yang berguna untuk pengambilan keputusan dan untuk menunjukkan akuntabilitas entitas pelaporan atas sumber daya yang dipercayakan kepadanya.

Dari penjelasan diatas dapat disimpulkan bahwa, laporan keuangan daerah merupakan laporan yang bertujuan untuk mengevaluasi atas penggunaan sumber daya yang telah digunakan pemerintah daerah. Serta melaporkan pertanggungjawaban terhadap penggunaan sumber daya kepada publik. Sebab dana yang digunakan dan dikelola oleh pemerintah pada dasar berasal dari publik dan publik berhak mendapatkan informasi atas penggunaan dana tersebut. Selain itu, pemerintah dituntut untuk menyajikan laporan keuangan yang terdiri dari Laporan Realisasi Anggaran, Neraca, Laporan Arus Kas dan Catatan atas Laporan Keuangan yang disesuaikan dengan Standar Akuntansi Pemerintah Tahun 2005. Hal tersebut sama halnya dengan tanggung jawab yang mestinya diberikan oleh pemerintah dalam penyampaian laporan keuangan. Menurut Mardiasmo (2002) tanggung jawab pada sektor publik ditinjau dari dua pola yaitu: (1) pertanggungjawaban vertikal (vertical accountability) adalah pertanggungjawaban atas pengelolaan dana kepada otoritas yang lebih tinggi, misalnya pertanggungjawaban pemerintah daerah kepada pemerintah pusat, dan pemerintah pusat kepada parlemen; (2) pertanggungjawaban horizontal (horizontal accountability) adalah pertanggungjawaban kepada masyarakat luas.

\section{Pemerintah Daerah}

Sistem pemerintah daerah yang di Indonesia saat ini bersifat otonomi daerah. Otonomi daerah adalah kewenangan daerah otonom untuk mengatur dan mengurus kepentingan masyarakat setempat menurut prakarsa sendiri berdasarkan aspirasi masyarakat sesuai dengan peraturan perundangundangan. Hal tersebut telah disesuaikan dengan UU nomor 22 tahun 1999 tentang Pemerintahan Daerah (Halim, 2007). Misi terhadap undang-undang tersebut adalah desentralisasi. Desentralisasi tidak hanya berarti pelimpahan wewenang dari pemerintah pusat ke pemerintah yang lebih rendah, tetapi juga pelimpahan beberapa wewenang pemerintah ke pihak swasta dalam bentuk privatisasi (Mardiasmo, 2002). Sampai saat ini, Negara Kesatuan Republik Indonesia memiliki 33 provinsi dan 497 kabupaten/kota yang terdiri dari 403 kabupaten dan 94 kota. Dari 33 provinsi tersebut, 5 di antaranya memiliki status khusus sebagai Daerah Khusus atau Daerah Istimewa yaitu: Aceh, Jakarta, Papua, Papua Barat, dan Yogyakarta.

Tujuan adanya otonomi daerah adalah mempercepat pertumbuhan ekonomi dan pembangunan daerah, mengurangi kesenjangan antardaerah, dan meningkatkan kualitas pelayanan publik agar lebih efisien dan responsif terhadap kebutuhan, potensi maupun karakteristik didaerah masing-masing (Bastian, 2006). Selain itu, manfaat yang dapat dihasilkan atas pelaksanaan desentralisasi yaitu, dapat mendorong peningkatan partisipasi masyarakat dalam pembangunan serta perbaikan alokasi sumber 
daya yang produktif (Mardiasmo, 2002). Dalam menjalankan sistem otonomi dan desentralisasi diharapkan setiap pemerintah mampu memberikan suatu laporan pertanggungjawaban terkait dengan sikap keterbukaan dan pertanggungjawaban terhadap penggunaan dana publik.

\section{Situs web Internet Pemerintah Daerah}

Situs web internet pemerintah daerah merupakan sebuah situs yang terdapat pada internet yang berisikan segala informasi tentang kondisi pemerintah daerah. Informasi-informasi yang dimaksud diantaranya adalah profil pemerintah daerah, potensi daerah, pembangunan daerah dan sebagainya. Situs web pemerintah daerah merupakan pengembangan aplikasi e- Goverment yang dilakukan oleh pemerintah. Hal ini didasarkan pada kemajuan perkembangan teknologi informasi yang dapat menunjang kemajuaan pembangunan pemerintah daerah.

Menurut Goechi.com (2010) saat ini pemerintah telah menggalakkan pemanfaatan teknologi informasi (internet) dalam menunjang aktifitas kegiatan pemerintahannya, baik pemerintah pusat maupun pemerintah daerah untuk menuju terwujudnya e-Government, yaitu sebuah konsep untuk mewujudkan terjadinya interaksi dan komunikasi baru antara pemerintah daerah yang satu dengan yang lainya, antara pemerintah daerah dengan pemerintah pusat, antara pemerintah dengan masyarakat, dan antara pemerintah dengan dunia usaha. Tujuan pembangunan website Pemerintah Daerah adalah untuk menunjang peningkatan pembangunan daerah dalam menjalankan fungsinya untuk kemajuan dan kesejahteraan masyarakat daerahnya.

Selain itu, ditinjau dari segi perkembangan teknologi dan informasi saat ini situs web merupakan salah satu media penyampaian informasi, khususnya informasi publik. Menurut Undangundang Nomor 14 Tahun 2008 Pasal 1 tentang Keterbukaan Informasi Publik, informasi publik adalah informasi yang dihasilkan, disimpan, dikelola, dikirim, dan/atau diterima oleh suatu badan publik yang berkaitan dengan penyelenggara dan penyelenggaraan negara dan/atau penyelenggara dan penyelenggaraan badan publik lainnya yang sesuai dengan Undang-Undang ini serta informasi lain yang berkaitan dengan kepentingan publik.

Jadi, dapat disimpulkan bahwa informasi publik merupakan semua informasi yang dibutuhkan oleh publik terkait dengan kepentingan masing-masing publik itu sendiri yang diatur juga oleh undang-undang. Dalam hal ini informasi publik yang difokuskan adalah kegiatan yang dilakukan oleh pemerintah daerah dalam hal penyampaian dan penyajian laporan keuangan daerah. Sebagaimana yang telah disebutkan dalam Undang-undang Nomor 14 Tahun 2008 yang menyatakan bahwa salah satu tujuan atas keterbukaan informasi publik adalah sebagai berikut mewujudkan penyelenggaraan negara yang baik, yaitu yang transparan, efektif dan efisien, akuntabel serta dapat dipertanggungjawabkan.

\section{Penelitian Sebelumnya}

Penelitian mengenai laporan keuangan dengan media internet, telah banyak dilakukan. Pada umumnya, penelitian-penelitian tersebut dilakukan untuk mengukur dan menilai tingkat pengungkapan informasi keuangan pada situs web sebuah internet perusahaan. Selain informasi keuangan, juga menampilkan informasi nonkeuangan. Penelitian yang dilakukan oleh Xiao, Yang \& Chow (2004) pada perusahaan di Cina yang menggunakan internet sebagai media penyampaian informasi keuangan (internet based corporate disclosure). Dimana, melalui internet based corporate disclosure dapat memberikan keuntungan yang lebih dalam bidang ekonomi, khusus dalam pasar modal untuk dapat memberikan infomasi langsung kepada stakeholder tentang kepemilikan saham. Dalam penelitian ini dapat diambil kesimpulan bahwa perusahaan yang sahamnya dimiliki oleh perorangan, cenderung mengungkapkan informasi keuangan yang lebih banyak dari pada kepemilikan saham yang dimiliki oleh pemerintah. 
Selain itu, terdapat penelitian yang dilakukan oleh Laswad, Fisher, \& Oyelere (2005) bahwa penyampaian laporan keuangan pemerintah dapat dilakukan dengan media internet (internet financial reporting). Hal tersebut terkait dengan keputusan beberapa pemerintah lokal di New Zealand untuk mempublikasikan informasi keuangan dengan internet. Selain itu, reformasi sektor publik di New Zealand membawa perubahan dalam penyajiaan laporan keuangan, dimana penyajian laporan keuangan di New Zealand beralih menjadi praktik sektor swasta. Penelitian ini menjelaskan bahwa pemerintah lokal yang melibatkan internet dalam pengungkapan informasi keuangan memiliki tingkat leverage yang lebih tinggi bagi pemerintah lokal setempat. Penelitian ini memberikan penjelasan bahwa pemerintah New Zealand menggunakan internet untuk memberikan informasi keuangan serta untuk meningkatkan upaya transparansi dan akuntabilitas keuangan yang lebih besar kepada publik.

Hal tersebut senada dengan tujuan penelitian yang dilakukan oleh Abdelsalam, Bryant, \& Street (2007), bahwa terdapat dua hal yang penting terkait penelitian yang dilakukan dengan corporate internet reporting (CIR). Pertama, penyampaian atas pengungkapan dengan menggunakan CIR di London menjadi peraturan baru untuk dapat meningkatkan transparansi. Kedua, memperluas suatu pembahasaan tentang pengukuran corporate governance dengan adanya pengungkapan dengan CIR. Jadi, penelitian ini memberikan kesimpulan bahwa untuk memberikan informasi pengungkapan yang lebih dipercaya tidak hanya dengan ketepatan waktu penyampaian tetapi ditambahkan dengan peraturan yang lebih dipercaya dan menarik perhatian investor.

\section{METODOLOGI PENELITIAN}

\section{Sampel Penelitian}

Sumber data diambil dari tiap-tiap situs web pemerintah daerah. Di mana, objek penelitian adalah situs web pemerintah daerah yang menampilkan informasi keuangan pemerintah daerah. Adapun rincian sumber data yaitu: (1) data berasal dari situs web pemerintah daerah dapat diakses; (2) memberikan informasi laporan keuangan daerah; (3) laporan keuangan pemeritah daerah yang dapat didownload atau tampil langsung di situs web dengan baik; (4) kelengkapan laporan keuangan daerah terdiri dari: laporan realisasi anggaran (LRA), laporan arus kas, neraca dan catatan atas laporan keuangan daerah; (5) data diakses mulai tanggal 14 sampai 28 Maret 2010 dengan mencakup periode informasi keuangan dari tahun 2007 sampai dengan 2009.

Populasi dari penelitian adalah situs web pemerintah daerah yang terdaftar sebagai situs resmi pemerintah di Indonesia. Penelitian ini dilakukan dengan mengumpulkan informasi laporan keuangan daerah yang dipublikasikan oleh situs web pemerintah daerah. Dimana, jumlah pemerintah daerah saat ini tercatat sebanyak 530 yang terdiri dari memiliki 33 provinsi dan 497 kabupaten/kota yang terdiri dari 403 kabupaten dan 94 kota. Dari jumlah pemerintah daerah yang ada di Indonesia, maka telah teridentifikasi sebanyak 392 situs web pemerintah daerah yang dimiliki oleh masing-masing pemerintah daerah di Indonesia yang dapat diakses, oleh semua pihak.

Setelah melakukan pengamatan terhadap 392 situs web pemerintah daerah, telah ditemukan bahwa sampel situs web pemerintah daerah yang memberikan kemudahan dalam mencari informasi keuangan adalah sebanyak 57 situs web pemerintah daerah. Dengan kriteria situs web yang akan diteliti untuk diambil sebagai sampel yaitu: (1) situs web dapat diakses dengan baik; (2) situs web memberikan kemudahan dalam mencari informasi keuangan daerah; (3) situs web memberikan kemudahan dalam mengakses data atau mendownload data laporan keuangan daerah. 
Tabel 1 Pemilihan Sampel

\begin{tabular}{lc}
\hline \multicolumn{1}{c}{ Keterangan } & Jumlah \\
\hline Jumlah Pemerintah Daerah di Indonesia & 530 \\
Daerah yang belum memiliki website & 138 \\
Daerah yang memiliki situs web pemerintah daerah yang dapat diakses & 392 \\
Daerah yang menampilkan informasi keuangan daerah pada situs web & 57 \\
Situs web pemerintah daerah yang dapat diakses tetapi belum ditemukan & 327 \\
publikasi informasi keuangan daerah & 8 \\
Situs web pemerintah daerah yang suspended ( terindikasi virus, sudah ditutup ) & 57 \\
Sampel yang digunakan dalam penelitian & \\
\hline
\end{tabular}

Di bawah ini adalah situs web pemerintah daerah yang dijadikan sampel.

Tabel 2 Sampel Situs Web yang Dijadikan Sampel Penelitian

\begin{tabular}{|c|c|c|c|c|c|}
\hline No & $\begin{array}{l}\text { Nama Provinsi/ } \\
\text { Kabupaten/Kota }\end{array}$ & Situs pemerintah daerah & No & $\begin{array}{l}\text { Nama Provinsi/ } \\
\text { Kabupaten/Kota }\end{array}$ & Situs pemerintah daerah \\
\hline 1 & Prov. Jambi & www.jambiprov.go.id & 29 & Kab.Barito Kuala & www.baritokualakab.go.id \\
\hline 2 & Prov. Sumatera Utara & www.sumutprov.go.id & 30 & Kab.Flores Timur & www.florestimurkab.go.id \\
\hline 3 & Prov. Sumatera Barat & www.sumbarprov.go.id & 31 & Kab.Luwu Timur & www.luwutimurkab.go.id \\
\hline 4 & Prov. Kepulauan Riau & www.kepriprov.go.id & 32 & Kab.Tana Toraja & www.torajakab.go.id \\
\hline 5 & Prov. Jawa Barat & www.jabarprov.go.id & 33 & Kab.Pinrang & www.pinrangkab.go.id \\
\hline 6 & Kab.Banyumas & www.banyumaskab.go.id & 34 & Kab.Barito Utara & www.baritoutarakab.go.id \\
\hline 7 & Kab.Kebumen & www.kebumenkab.go.id & 35 & Kab.Jayawijiya & www.jayawijayakab.go.id \\
\hline 8 & Kab. Lamongan & www.lamongan.go.id & 36 & Kab.Tanah Datar & www.tanahdatar.go.id \\
\hline 9 & Kab.Bone & www.bone.go.id & 37 & Kab.SerdangBedagai & www.serdangbedagaikab.go.id \\
\hline 10 & Kab.Semarang & www.semarangkab.go.id & 38 & Kab.Pelalawan & www.pelalawankab.go.id \\
\hline 11 & Kab.Bandung & www.bandung.go.id & 39 & Kab.Muaro Jambi & www.muarojambi.go.id \\
\hline 12 & Kab.KulonProgo & www.kulonprogokab.go.id & 40 & Kab.Tanjung Jabung Barat & www.tanjabbarkab.go.id \\
\hline 13 & Kab.Garut & www.garutkab.go.id & 41 & Kab.Grobogan & www.grobogan.go.id \\
\hline 14 & Kab.Bekasi & www.bekasikab.go.id & 42 & Kab.Rembang & www.rembang.go.id \\
\hline 15 & Kab.Magelang & www.magelangkab.go.id & 43 & Kab.Barru & www.barru.go.id \\
\hline 16 & Kab. Jepara & www.jepara.go.id & 44 & Kab.Ponorogo & www.ponorogo.go.id \\
\hline 17 & Kab.Gunung Kidul & www.gunungkidul.go.id & 45 & Kab.Kudus & www.kuduskab.go.id \\
\hline 18 & Kab.Bantul & www.bantul.go.id & 46 & Kota.Banda Aceh & www.bandaacehkota.go.id \\
\hline 19 & Kab.Sleman & www.slemankab.go.id & 47 & Kota Cimahi & www.cimahikota.go.id \\
\hline 20 & Kab.Pacitan & www.pacitan.go.id & 48 & Kota Kendari & www.kendari.go.id \\
\hline 21 & Kab.Lumajang & www.lumajang.go.id & 49 & Kota Makassar & www.makassarkota.go.id \\
\hline 22 & Kab.Mojokerto & www.mojokertokab.go.id & 50 & Kota Malang & www.malangkota.go.id \\
\hline 23 & Kab.Malang & www.malangkab.go.id & 51 & Kota Yogya & www.jogja.go.id \\
\hline 24 & Kab.Bojonegoro & www.bojonegoro.go.id & 52 & Kota Banjar & www.banjar-jabar.go.id \\
\hline 25 & Kab.Jember & www.pemkabjember.go.id & 53 & Kota Surakarta & www.surakarta.go.id \\
\hline 26 & Kab.Jembrana & www.jembranakab.go.id & 54 & Kota Ambon & www.ambon.go.id \\
\hline 27 & Kab.Kupang & www.kab-kupang.go.id & 55 & Kota Tasikmalaya & www.tasikmalayakota.go.id \\
\hline \multirow[t]{2}{*}{28} & Kab.Lebak & www.lebakkab.go.id & 56 & Kota Tangerang & www.kotatangerang.go.id \\
\hline & & & 57 & Kota Semarang & www.semarang.go.id \\
\hline
\end{tabular}

Teknik pengambilan sampel dalam penelitian ini tergolong teknik nonprobability sampling. Menurut Sugiono (2008) teknik nonprobability sampling adalah teknik pengambilan sampel yang tidak memberi peluang atau kesempatan sama bagi setiap unsur anggota populasi untuk dipilih menjadi sampel.

\section{Analisis Data}

Data yang digunakan sebagai objek penelitian dalam skripsi ini adalah data keuangan pemerintah daerah. Kemudian tiap daerah akan ditelusuri tentang keberadaan situs web resminya. Kemudian tiap situs web pemerintah daerah akan ditelusuri dan dianalisa mengenai kelengkapan informasi laporan keuangannya yang dipublikasi kepada publik. Kemudian informasi atas data laporan 
keuangan yang sudah ditemukan diunduh. Kemudian data lanjutan ini akan diolah dan dianalisis berdasarkan kriteria penilaian (check list) yang digunakan. Setelah kelengkapan terhadap laporan keuangan daerah didapat, maka dapat diambil kesimpulan atas penelitian ini.

Kriteria penilaian diatas didasarkan pada kesesuaian komponen laporan keuangan pemerintah daerah dengan Standar Akuntansi Pemerintah (SAP) menurut PP Nomor 24 Tahun 2005. Serta mengacu pada informasi keuangan daerah yang disajikan dengan baik pada setiap situs web, dimana informasi keuangan tersebut salah satunya adalah ringkasan realisasi Anggaran Pendapatan dan Belanda Daerah (APBD). Setelah dilakukan analisa data berdasarkan kriteria penilaian, maka data tersebut disajikan dengan penyajian data dalam bentuk tabel. Dimana tabel tersebut akan menjelaskan tentang kualitas informasi keuangan daerah yang di terbitkan pada situs web pemerintah daerah. Serta menunjukkan sejauh mana kemajuan situs web pemerintah daerah dalam menggunakan media internet dalam penyampaian informasi keuangan.

\section{HASIL DAN PEMBAHASAN}

\section{Evaluasi Konten Situs Web Internet terhadap Kelengkapan Informasi Keuangan}

Pada tahap analisis ini bertujuan untuk lebih menjelaskan secara rinci terhadap keberadaan situs web pemerintah daerah. Yang mana unsur utama terhadap situs web adalah isi konten yang memberikan keterangan atas disajikan-nya informasi keuangan daerah. Hal ini juga didasarkan pada hasil kriteria penilaian (check list) terhadap pengumpulan informasi keuangan yang ditampilkan oleh tiap-tiap situs web. Dari hasil evaluasi terhadap tiap-tiap situs web pemerintah daerah, maka dapat dihasilkan bahwa informasi keuangan lebih banyak memberikan informasi ringkasan APBD dibandingkan laporan keuangan pemerintah daerah yang sesuai SAP. Hal ini tersaji dalam tabel 3 dan 4.

Tabel 3 Persentase Situs Web yang Menyajikan SAP

Berdasarkan pada Keseluruhan Daerah yang Memiliki Situs Web

\begin{tabular}{lcc}
\multicolumn{1}{c}{ Keterangan } & Jumlah & Persentase \\
\hline Laporan keuangan sesuai SAP & 9 & $2,30 \%$ \\
Informasi keuangan berupa APBD & 40 & $10,20 \%$ \\
Temuan informasi keuangan selain SAP dan APBD & 7 & $1,79 \%$ \\
Laporan keuangan ada tetapi datanya tidak dapat didownload & 1 & $0,26 \%$ \\
Jumlah situs web yang menampilkan informasi keuangan & 57 & $14,54 \%$ \\
\hline
\end{tabular}

Tabel 4 Persentase Situs Web yang Menyajikan SAP

Berdasarkan pada Keseluruhan Daerah yang Menampilkan Informasi Keuangan.)

\begin{tabular}{lcc}
\hline \multicolumn{1}{c}{ Keterangan } & Jumlah & Persentase \\
\hline Laporan keuangan sesuai SAP & 9 & $15,79 \%$ \\
Informasi keuangan berupa APBD & 40 & $70,18 \%$ \\
Temuan informasi keuangan selain SAP & 7 & $12,28 \%$ \\
Laporan keuangan tetapi datanya tidak dapat didownload & 1 & $1,75 \%$ \\
Jumlah situs web yang menampilkan informasi keuangan & 57 & $100,00 \%$ \\
\hline
\end{tabular}

Keterangan; Temuan informasi keuangan selain SAP terdiri dari; Alokasi Dana Konsentrasi, Koreksi Neraca, Alokasi Dana, Target dan Realisasi dan Perkembangan APBD. 


\section{Evaluasi Situs web yang Memuat Laporan Keuangan Sesuai SAP}

Dari 57 situs web pemerintah daerah yang menyajikan informasi keuangan hanya 9 situs web atau $15,79 \%$ atau hanya $2,30 \%$ dari keseluruhan situs web pemerintah daerah telah mampu menyajikan informasi keuangan sesuai dengan komponen SAP. Dalam proses evaluasi ini fokus utama evaluasi hanya pada 9 situs web pemerintah daerah yang menyajikan laporan keuangan pemerintah daerah sesuai dengan komponen SAP. Hal ini tertuang dalam tabel 5:

Tabel 5 Situs Web Pemerintah Daerah yang Telah Sesuai dengan SAP

\begin{tabular}{clccc}
\hline No & \multicolumn{1}{c}{ Situs web } & Neraca & $\begin{array}{c}\text { Laporan } \\
\text { Realisasi } \\
\text { Anggaran (LRA) }\end{array}$ & $\begin{array}{c}\text { Laporan Arus } \\
\text { Kas (LAK) }\end{array}$ \\
\hline 1 & Provinsi Jambi & $\mathrm{v}$ & $\mathrm{V}$ & $\mathrm{V}$ \\
2 & Kab. Lamongan & $\mathrm{v}$ & $\mathrm{V}$ & - \\
3 & Kab.Kulonprogo & $\mathrm{v}$ & $\mathrm{V}$ & $\mathrm{V}$ \\
4 & Kab. Kebumen & $\mathrm{v}$ & $\mathrm{V}$ & $\mathrm{V}$ \\
5 & Kab.Sleman & $\mathrm{v}$ & - & $\mathrm{V}$ \\
6 & Kab.Bekasi & - & $\mathrm{V}$ & - \\
7 & Kota Banda Aceh & $\mathrm{v}$ & $\mathrm{V}$ & $\mathrm{V}$ \\
8 & Kota Semarang & $\mathrm{v}$ & $\mathrm{V}$ & $\mathrm{V}$ \\
9 & Kota Cimahi & $\mathrm{v}$ & $\mathrm{V}$ & - \\
\hline
\end{tabular}

Dari hasil evaluasi diatas mengenai evaluasi laporan keuangan pemerintah daerah, maka disimpulkan bahwa komponen laporan keuangan yang disajikan oleh 9 situs web telah memenuhi semua komponen SAP yaitu, neraca, laporan arus kas, dan laporan realisasi. Namun, terdapat 1 situs web yang hanya menampilkan laporan realisasi anggaran saja. Sehingga dapat dijelaskan bahwa laporan keuangan yang disajikan oleh 9 situs web dinilai telah cukup lengkap dan baik dalam memberikan informasi keuangan berupa laporan keuangan sesuai SAP.

Selain itu, ke-9 situs web juga telah menunjukkan tanggungjawabnya kepada publik dengan memberikan informasi laporan keuangan kepada publik (horizontal accountability). Dilihat dari segi transparansi, ke- 9 situs web pemerintah daerah telah cukup terbuka dalam pengelolaan dana publik melalui penyampaian informasi laporan keuangan dengan media internet. Sehingga dapat disimpulkan bahwa laporan keuangan daerah dengan media internet memberikan manfaat dalam penyebaran informasi atas pengunaan dana publik kepada masyarakat luas.

\section{PENUTUP}

Dalam penelitian ini, lebih difokuskan kepada pengungkapan laporan keuangan daerah yang ditampilkan pada situs web pemerintah daerah. Dimana laporan keuangan yang disajikan pada situs web berpedoman pada SAP. Dan dapat disimpulkan dari hasil penelitian bahwa transparansi informasi keuangan daerah dan kesesuaiannya dengan SAP masih sangat rendah. .Masih rendahnya transparansi bisa dilihat dari 530 jumlah pemerintah daerah yang ada di Indonesia yang terdiri dari provinsi, kabupaten dan kota yang memiliki situs web pemerintah daerah adalah sebanyak 392 situs web atau 73,96\%. Dari 392 situs web, ternyata terdapat 327 situs web atau 83,42\% yang dapat diakses dengan baik, namun keberadaan informasi keuangan yang disajikan belum dapat ditemukan dengan baik. Akhirnya hanya 57 situs web atau 14,54\% yang mampu memberikan informasi keuangan daerah dengan baik dan dapat diakses datanya. Dari 57 situs web yang digunakan sebagai sampel penelitian maka terdapat 9 situs web yang menyajikan informasi laporan keuangan sesuai SAP atau 15,79\% atau hanya sebesar 2,30\% dari keseluruhan jumlah daerah yang memiliki situs web. 
Dan informasi keuangan daerah pada tiap-tiap situs web yang paling banyak disajikan adalah informasi keuangan berupa ringkasan APBD sebanyak 40 situs web atau 70,18\% atau hanya sebesar 10,20\% dari keseluruhan jumlah daerah yang memiliki situs web. Dari situs web yang memuat informasi tentang SAP, maka kualitas pengungkapan informasi yang disajikan dinilai telah cukup lengkap. Hal ini didasarkan dari 9 situs web yang menyajikan informasi laporan keuangan sesuai SAP telah memuat semua komponen SAP pada tiap-tiap laporan keuangan, yaitu laporan realisasi anggaran, neraca dan laporan arus kas.

Keterbatasan dalam penelitian ini adalah sangat minimnya penelitian mengenai pengungkapan laporan keuangan daerah di Indonesia. Sehingga sulit untuk menemukan bahan literatur yang dapat mendukung penelitian ini.Permasalahan yang timbul adalah penyusunan kriteria penilaian, yang mana kriteria penyusunan sebagai instrumen penelitian baru hanya sebatas penentuan informasi yang harusnya tersedia pada situs web pemerintahan daerah. Selain itu, belum ada peraturan yang resmi bahwa pada tiap-tiap situs web pemerintah daerah diwajibkan menyajikan laporan keuangan daerah sesuai dengan SAP. Masalah lainya adalah terkait dengan kondisi terhadap setiap situs web, sehingga situs web yang dijadikan suatu sampel mungkin memiliki beberapa indikasi terhadap pemaparan informasi keuangan. Penelitian berikutnya bisa melihat lebih lanjut tentang faktor-faktor yang menentukan suatu pemerintah daerah mengungkapan informasi keuangan dan laporan keuangannya di situs internet. Dengan demikian kita dapat melihat faktor apa saja yang mendorong keterbukaan informasi dan akuntabilitas publik suatu Pemerintah Daerah.

\section{DAFTAR PUSTAKA}

Abdelsalam, O. H., Bryant, S. M. \& Street, D. L. (2007). An examination of the comprehensiveness of corporate internet reporting provided by London listed companies. Journal of International Accounting Research.

Bastian, I. (2006). Akuntansi sektor publik: suatu pengantar. Jakarta: Erlangga.

Bastian, I., \& Soepriyanto, G. (2002). Sistem akuntansi sektor publik: buku 1. Jakarta: Salemba Empat.

Departemen Dalam Negeri (2006) Peraturan Menteri Dalam Negeri Nomor 13 Tahun 2006. Pedoman Pengelolaan Keuangan Daerah.

Goechi.com (2010) , Satu Langkah Menuju Implementasi e-Government bagi Pemerintah Daerah di Indonesia, Diunduh dari http://www.goechi.com/webpemda.html

Halim, A. (2007). Akuntansi sektor publik: akuntansi keuangan daerah (3rd ed.). Jakarta: Salemba Empat.

Laswad, F., Fisher, R., \& Oyelere, P. (2005). Determinants of voluntary internet financial reporting by local government authorities. Journal of Accounting and Public Policy.

Mardiasmo. (2002). Akuntansi sektor publik. Yogyakarta: Andi Yogyakarta.

Republik Indonesia. (2005). Peraturan Pemerintah Nomor 24 Tahun 2005 tentang Standar Akuntansi Pemerintahan. Jakarta: Salemba Empat. 
Republik Indonesia. (2008). Undang-Undang Nomor 14 Tahun 2008 tentang Keterbukaan Informasi Publik. Diunduh pada 19 Juli 2010.

Sugiyono. (2008). Metode penelitian bisnis. Bandung: CV Alfabeta.

Xiao, J. Z., Yang, H., \& Chow, C. W. (2004). The determinants and characteristics of voluntary internet-based disclosures by listed Chinese companies. Journal of Accounting and Public Policy. 